\title{
О.А. Войленко
}

\section{Зміни розміру локалізованого нирково-клітинного раку під впливом неоад'ювантної таргетної терапії}

\author{
Національний інститут раку, Київ \\ Одержано 02.01.2019 \\ Прийнято до друку 22.01.2019 \\ DOI: $10.32471 /$ clinicaloncology.2663-466X.38.22124
}

\begin{abstract}
Мета - визначити ефективність використання неоад'ювантної таргетної терапії (ТT) у лікуванні хворих на локалізований нирково-клітинний рак (НКР). Об'єкт і методи. 58 пацієнтів із локалізованим НКР, яким в період 32017 по 2018 р. проведено 2 блоки неоад'ювантної ТТ із визначенням об'єктивної відповіді на лікування та подальшим оперативним втручанням.

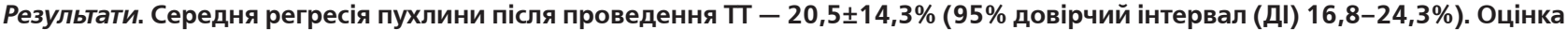
за RECIST 1.1: стабілізація - 44 (76,9\%) випадки; часткова регресія - 14 (24,1\%); повна регресія - 0; прогресія захворювання - 0. Проведення неоад'ювантної ТТ сприяло зменшенню розміру НКР в середньому на 12,3 мм 3 60,8 19,7 мм (95\% ДІ 55,7-66) до 48,5 6 ,4 мм (95\% ДІ 44,2-52,8) (t-test; p<0,001) та збільшенню медіани об'єму функціонуючої паренхіми нирки на 21\% 362 (57-77) до 83 (70-90) мм (Mann - Whitney U Test; p<0,001), що дозволило в 53 випадках (91,4\%) провести резекцію нирки. Висновки. Неоад'ювантна ТТ у хворих на локалізований НКР зумовила регресію пухлини у середньому на 20,5 $14,3 \%$, збільшення медіани об'єму функціонуючої паренхіми нирки на $21 \%(p<0,001)$, що дає можливість проведення подальшого органозберігаючого оперативного лікування.
\end{abstract}

Ключові слова: нирково-клітинний рак; неоад'ювантна таргетна терапія.

Резекція нирки стала операцією вибору в лікуванні локалізованого нирково-клітинного раку (НКР) [1, 2]. Ї̈і онкологічна та функціональна ефективність доведена у численних клінічних дослідженнях. При цьому чітко розроблених показань до резекції нирки досі не існує.

У випадку розміщення пухлини у воротах нирки або при пухлинах великого розміру (>4 см) у клінічній практиці частіше застосовується радикальна нефректомія, яка значно погіршує виживаність хворих за рахунок хронічної ниркової недостатності (ХНH) та помітно знижує якість їх життя [3-6]. Зменшення розмірів пухлини в цій ситуації може змінити тактику на користь проведення резекції нирки, що дасть значні преференції хворому. Досягти цієї мети можливо за рахунок призначення таргетної терапії (ТT) в неоад’ювантному режимі.

Аналіз сучасної літератури показав, що використання неоад'ювантної ТТ при локалізованому НКР проводилося лише в окремих клінічних випадках та в невеликих ретроспективних групах за імперативними показаннями (пухлина єдиної нирки, двобічні пухлини нирок, патологія протилежної нирки, яка значно порушує ії функцію) [7-12], а рандомізованих досліджень із застосуванням неоад'ювантної ТТ для лікування локалізованого НКР не було взагалі. Враховуючи вищеперераховане, у науково-дослідному відділенні пластичної та реконструктивної онкоурології заплановано та проводиться перспективне рандомізоване дослідження з вивчення ефективності неоад'ювантної ТТ в лікуванні локалізованого НКР, попередні результати якого представлено в цій статті.

Мета дослідження - визначити ефективність використання неоад’ювантної ТТ в лікуванні хворих на локалізований НКР.

\section{КЛІНІЧНИЙ МАТЕРІАЛ}

Клінічному аналізу підлягали 58 пацієнтів із локалізованим HKP (T1-T2N0M0), яким в період з 2017 по 2018 р. в науково-дослідному відділенні пластичної та реконструктивної онкоурології Національного інституту раку проведено 2 блоки неоад'ювантної ТТ препаратами першої лінії.

Оцінку ефективності лікування виконували на основі променевих методів візуалізації (ультразвукове дослідження, комп'ютерна томографія, магнітно-резонансна томографія, урографія), які використовували як при первинному обстеженні, так і при всіх контрольних обстеженнях. Регресію первинної пухлини проводили за критеріями оцінки відповіді солідних пухлин на терапію (Response Evaluation Criteria in Solid Tumors - RECIST) [13] та відсотком регресії пухлини.

TT проводили за стандартною схемою: пазопаніб 800 мг щоденно перорально протягом 2 міс; сунітиніб по 50 мг щоденно протягом 28 діб, з перервою в прийомі препарату протягом 14 діб та повторним 28-денним курсом терапії.

Клінічна характеристика хворих: чоловіків - $39(67,2 \%)$, жінок - 19 (32,8\%). Вік пацієнтів коливався від 26 до 72 років і в середньому становив $55,3 \pm 10,3$ року (95\% довірчий інтервал (ДІ) 52,6-58), ЕСОG статус - 0 балів (0-1; 95\% ДІ 25-75\%). Розміри пухлинного ураження стано-

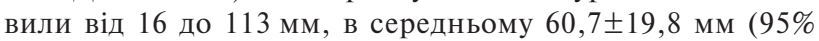
ДІ 55,5-66). Загальна швидкість клубочкової фільтрації

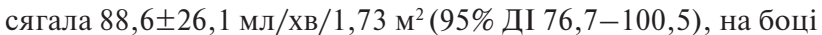

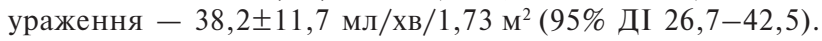
Половина пацієнтів, а саме 29 (50\%), мали супутні патології, серед них: артеріальна гіпертензія - у $25(43,1 \%)$, ожиріння - у $16(27,6 \%)$, кісти контралатеральної нирки у $7(12,1 \%)$, сечокам'яна хвороба - у $5(8,6 \%)$, цукровий діабет - у $2(3,4 \%)$, перенесений в анамнезі інфаркт міокарда - в $1(1,7 \%)$ хворого. Усі пацієнти були зі світлоклітинним типом НКР. Діагноз підтверджено за допомогою пункційної біопсії, виконаної до проведення ТТ та оперативного втручання.

Показання до проведення неоад'ювантної ТТ були імперативними (19 $(32,8 \%)$ випадків: двобічний НКР - $7(24,1 \%)$, НКР єдиної нирки $-5(8,6 \%))$ та елективними $(39(67,2 \%)$ випадків: центральне розміщення НКР > 20 мм - 21 (36,2\%), периферичне або полярне розміщення НКР, що поширюється на нирковий синус при об'ємі функціонуючої паренхіми нирки $>50 \%-18(31,0 \%))$.

Статистичну обробку отриманих результатів проводили за допомогою програмного забезпечення SPSS. Оцінку неперервних даних у групі виконували за побудовою діаграм розподілу за критерієм Колмогорова - Смирнова. Описова статистика включала обчислення середньої величини зі стандартним відхиленням $(\mathrm{M} \pm \mathrm{SD})$ або медіани $(\mathrm{Me})$ з 25-75 процентилями. Порівняння кількісних показників у групах проводили з використанням критерію Манна Уїні, якісних - критерію Пірсона. Статистично значущими 
відмінностями вважали вірогідності помилки 1 -го роду <5\% $(\mathrm{p}<0,05)$.

\section{РЕЗУЛЬТАТИ}

Перш за все ми оцінювали відсоток регресії пухлини на основі мультиспіральної комп'ютерної томографії (МСKT) органів грудної, черевної порожнини та малого таза з болюсним контрастним підсиленням на тому ж томографі з метою виключення похибки різних апаратів. Слід відмітити, що даних про наявність регіонарного та віддаленого метастазування не виявлено в жодному дослідженні. Відсоток регресії пухлини в кожному окремому випадку представлено на рис. 1.

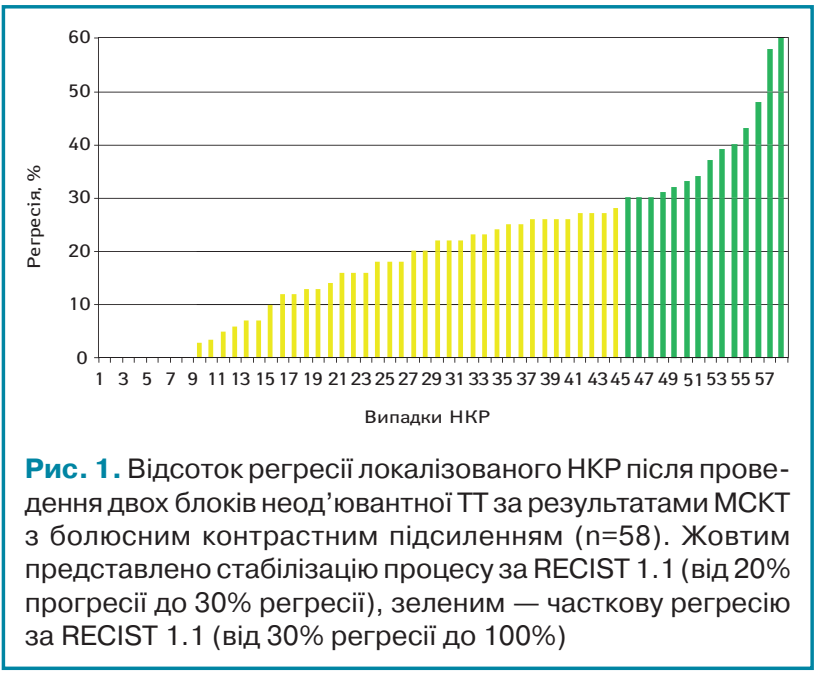

Дані, наведені на рис. 1, свідчать, що в більшості випадків після проведення неоад'ювантної ТТ розмір пухлини зменшився. При цьому частка регресії пухлини коливалася від 0 до $60 \%$ і в се-

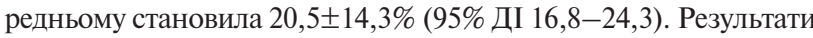
оцінки регресії пухлини за RECIST 1.1 представлено в табл. 1.

Таблиця 1. Оцінка об'єктивної відповіді за RECIST 1.1 локалізованого НКР після проведення неоад'ювантної ТТ за результатами МСКТ 3 болюсним контрастним підсиленням $(\mathrm{n}=58)$

\begin{tabular}{lcc}
\hline \multicolumn{1}{c}{ Показник } & $\mathbf{n}(\%)$ & $\begin{array}{c}\text { Медіана відсотка регресії } \\
\text { [25-75\%] }\end{array}$ \\
\hline Прогресія & 0 & - \\
Стабілізація & $44(75,9)$ & $16[5,5-23,5]$ \\
Часткова регресія & $14(24,1)$ & $35,5[31-43]$ \\
Повна відповідь & 0 & - \\
\hline
\end{tabular}

Як видно з табл. 1 та рис. 1, за результатами проведення неоад'ювантної ТТ прогресія захворювання не була відмічена в жодному випадку. Відсутність відповіді на проведення ТТ (0\% регресіi) відзначена у 8 (13,8\%) випадках. При цьому більшість пацієнтів мала незначну позитивну відповідь на проведення TT за RECIST 1.1 (від 3 до 29\% регресії локалізованого НКР), яка траплялася в 44 (76,9\%) випадках. Часткова відповідь за RECIST 1.1 відмічена в $14(24,1 \%)$ випадках і максимально сягала $60 \%$. На жаль, у жодному випадку не констатовано повної відповіді локалізованого НКР на проведення неоад'ювантної ТТ.

Результати порівняння розмірів пухлини нирки до та після проведення неоад'ювантної ТТ у хворих на локалізований НКР представлено в табл. 2 та в графічному вигляді - на рис. 2.

Таблиця 2. Розміри пухлини нирки до та після проведення неоад'ювантної ПТ за результатами МСКТ з болюсним контрастним підсиленням $(\mathrm{n}=58)$

\begin{tabular}{lccc}
\hline \multicolumn{1}{|c}{ Показник } & $\begin{array}{c}\text { Основна } \\
\text { група } \\
\text { до проведення TT } \\
(\mathbf{n = 5 8 )}\end{array}$ & $\begin{array}{c}\text { Основна } \\
\text { група } \\
\text { після } \\
\text { проведення TT } \\
(\mathbf{n = 5 8 )}\end{array}$ & $\begin{array}{c}\text { Статистична } \\
\text { оцінка }\end{array}$ \\
\hline Розмір пухлини & $60,8 \pm 19,7$ & $48,5 \pm 16,4$ & $\mathrm{t}$-test; \\
нирки, мм (95\% ДІ) & $(55,7-66,0)$ & $(44,2-52,8)$ & $\mathrm{p}<0,001$ \\
\hline
\end{tabular}

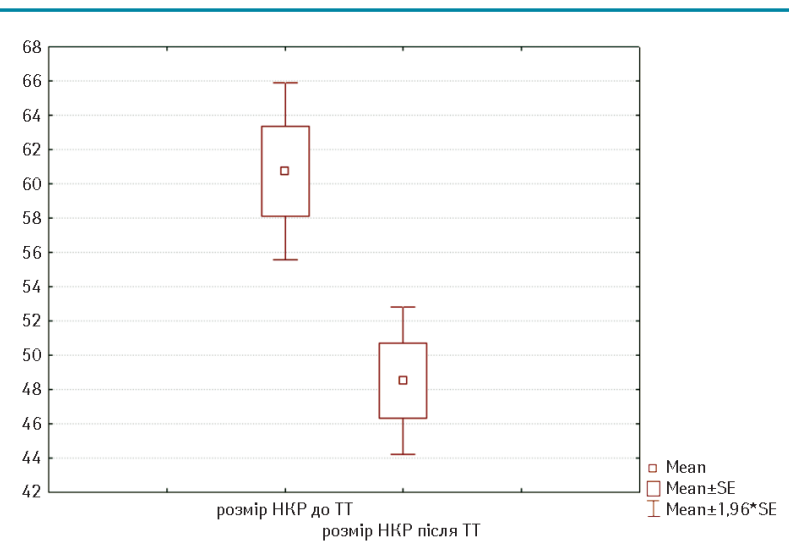

Рис. 2. Порівняльна оцінка середніх розмірів локалізованого НКР до та після проведення неоад'ювантної ТТ за результатами МСКТ з болюсним контрастним підсиленням $(n=58)$

Як видно з табл. 2 та рис. 2, проведення двох блоків неоад'ювантної ТТ у хворих на локалізований НКР дозволило достовірно (t-test; $\mathrm{p}<0,001)$ зменшити середній розмір пухлини нирки на 12,3 мм з 60,8 $\pm 19,7$ (95\% ДІ 55,7-66,0) до $48,5 \pm 16,4$ мм $(95 \% 44,2-52,8)$, що відіграло в ситуації локалізованого НКР ключову роль у виборі методу хірургічного втручання на користь органозберігаючого оперативного лікування, яке виконано в $91,4 \%$ випадків.

Одним із ключових критеріїв, що може вплинути на вибір методу лікування хворих на локалізований НКР, є об’єм функціонуючої паренхіми нирки, що входить до NCIUнефрометрії $[14,15]$. Саме тому нами виконано порівняльний аналіз цього показника до та після проведення неоад'ювантної ТТ у хворих на локалізований НКР, результати якого представлено в табл. 3 та в графічному вигляді - на рис. 3 .

Таблиця 3. Об'єм функціонуючої паренхіми нирки до та після проведення неоад'ювантної ТТ в основній групі за результатами МСКТ з болюсним контрастним підсиленням ( $\mathrm{n}=58)$

\begin{tabular}{|c|c|c|c|}
\hline Показник & $\begin{array}{c}\text { Основна } \\
\text { група } \\
\text { до проведення ТT } \\
(\mathrm{n}=58)\end{array}$ & $\begin{array}{c}\text { Основна } \\
\text { група після } \\
\text { проведення } \Pi \\
(n=58)\end{array}$ & $\begin{array}{c}\text { Статистична } \\
\text { оцінка }\end{array}$ \\
\hline $\begin{array}{l}\text { Об'єм функціону- } \\
\text { ючої паренхіми, } \\
\% \text { [25-75\%]) }\end{array}$ & $62[57-77]$ & 83 [70-90] & $\begin{array}{c}\text { U Test } \\
\text { Манна - Уїтні; } \\
\text { p<0,001 }\end{array}$ \\
\hline
\end{tabular}

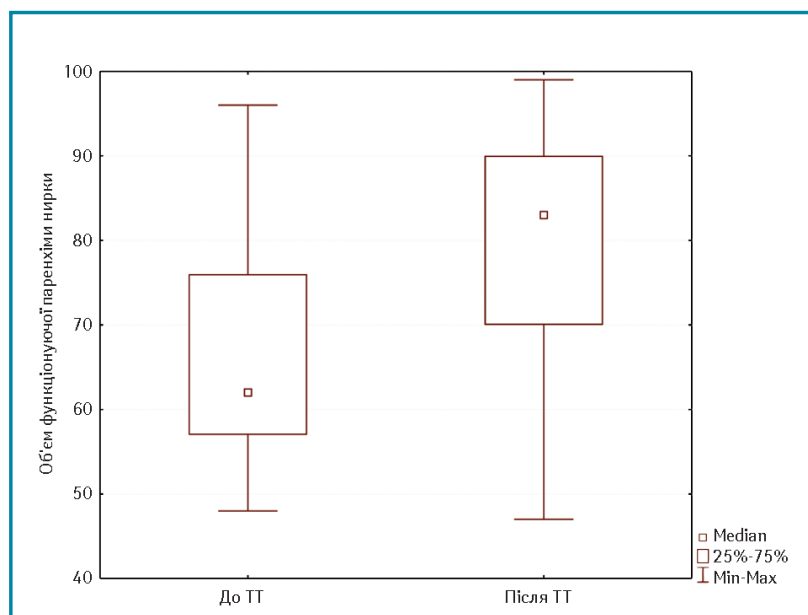

Рис. 3. Порівняльна оцінка медіани функціонуючої паренхіми нирки локалізованого НКР до та після проведення неоад'ювантної ТТ основної групи за результатами МСКТ з болюсним контрастним підсиленням $(n=58)$ 
Як видно з табл. 3 та рис. 3, проведення двох блоків неоад'ювантної ТТ у хворих на локалізований НКР дозволило достовірно ( $<0,001)$ збільшити медіану об'єму функціонуючої паренхіми нирки на $21 \%$ з 62 (57-77) до 83 (70-90) мм.

\section{ОБГОВОРЕННЯ}

Зважаючи на те що резекція нирки є операцією вибору в лікуванні пацієнтів з локалізованим НКР, а ії онкологічна та функціональна ефективність доведена в численних клінічних дослідженнях порівняно з радикальною нефректомією, що в першу чергу зумовлено більшою кількістю збереженої паренхіми нирки, основними напрямками наукових пошуків в онкоурології є заходи з розробки методів максимального збереження функціонального об'єму нирки, одним з яких може бути проведення неоад'ювантної ТТ у хворих на локалізований НКР.

Використання комбінованого лікування НКР в такому вигляді може зменшити розмір пухлини нирки з подальшою вищою вірогідністю проведення органозберігаючого лікування при розміщенні пухлини у воротах нирки або при пухлинах великого розміру ( $>4$ см), у тому числі у випадках імперативних показань до органозбереження. Зменшення об’єму пухлини в лікуванні локалізованого НКР направлене перш за все на покращення функціональних результатів та збереження відсотка функціонуючої паренхіми нирки.

Важливо відмітити, що більшість первинних світлоклітинних нирково-клітинних карцином зменшуються в розмірі та за хірургічною складністю під впливом ТТ, що дозволяе розглядати варіант хірургічного збереження нирки. Проте, враховуючи невелику вибірку пацієнтів у дослідженнях [9-12], доцільним є вивчення ролі обраного лікування на більш широких досліджуваних групах.

В основу принципу використання неоад'ювантної ТТ при НКР закладено концепцію підвищення безпеки процедури та покращення локорегіонарного контролю [16]. Потенційна перевага використання цього підходу полягає в циторедуктивному ефекті вказаної терапії та переведенні пацієнтів, котрі повинні були підлягати органовиносному лікуванню, до числа тих, яким показана резекція нирки. Ефективність такого виду лікування була досліджена при застосуванні сунітинібу, сорафенібу, а пізніше - пазопанібу та акситинібу [9-12].

Представлені в нашій роботі результати дослідження ефективності проведення неоад'ювантної ТТ в лікуванні хворих на локалізований НКР виявилися доволі перспективними. Висока клінічна ефективність неоад'ювантної ТТ в більшості випадків зумовлює зменшення розмірів пухлини нирки та підвищує перспективу можливої подальшої органозберігаючої тактики лікування, що дозволить значно знизити вірогідність розвитку ХНН, збільшити тривалість та підвищити якість життя пацієнтів внаслідок зниження інвалідизації.

Такий підхід дозволяє полегшити вибір хірургічної тактики при анатомічно складних пухлинах нирки. Важливим фактом $€$ те, що використання неоад’ювантного лікування в онкології направлене на зменшення кількості побічних проявів та покращення переносимості обраної терапії завдяки наявності двох функціонуючих нирок при максимальному об'ємі функціонуючої паренхіми, що значно підвищує дезінтоксикаційні можливості організму в цілому.

\section{висновок}

Проведення неоад'ювантної ТТ у хворих на локалізований НКР сприяло достовірній регресії пухлини у середньому на 20,5 $\pm 14,3 \%$, збільшенню медіани об'єму функціонуючої паренхіми нирки на $21 \%$ при розмірі первинної пухлини $60,7 \pm 19,8$ мм, що дає можливість проведення подальшого органозберігаючого оперативного лікування і дозволить значно знизити вірогідність розвитку ХНН, збільшити тривалість та підвищити якість життя пацієнтів внаслідок зниження інвалідизаціі.

\section{СПИСОК ВИКОРИСТАНОЇ ЛІТЕРАТУРИ}

1. NCCN Guidelines Version 2.2019. Kidney Cancer. Retrieved from https://www.nccn.org/professionals/physician_gls/pdf/kidney.pdf.

2. EAU Guidelines on Renal Cell Carcinoma 2018 ISBN/EAN: 978-94-92671-01-1. Retrieved from https://uroweb.org/guideline/renal-cell-carcinoma.

3. Smith D.H., Thorp M.L., Gurwitz J.H. et al. (2013) Chronic kidney disease and outcomes in heart failure with preserved versus reduced ejection fraction: the Cardiovascular Research Network PRESERVE Study. Circ. Cardiovasc. Qual. Outcomes, 6(3): 333-342. doi: 10.1161/CIRCOUTCOMES.113.000221.

4. Go A.S., Chertow G.M., Fan D. et al. (2004) Chronic kidney disease and the risks of death, cardiovascular events, and hospitalization. N. Engl. J. Med., 351(13): 12961305. doi: 10.1056/NEJMoa041031.

5. Herzog C.A., Asinger R.W., Berger A.K. et al. (2011) Cardiovascular disease in chronic kidney disease. A clinical update from Kidney Disease: Improving Global Outcomes (KDIGO). Kidney Int., 80(6): 572-586. doi: 10.1038/ki.2011.223.

6. Huang W.C., Levey A.S., Serio A.M. et al. (2006) Chronic kidney disease after nephrectomy in patients with renal cortical tumours: a retrospective cohort study. Lancet Oncol., 7(9): 735-740. doi: 10.1016/S1470-2045(06)70803-8.

7. Powles T., Kayani I., Blank C. et al. (2011) The safety and efficacy of sunitinib before planned nephrectomy in metastatic clear cell renal cancer. Ann. Oncol., 22(5): 1041-1047. doi: 10.1093/annonc/mdq564.

8. Silberstein J.L., Millard F., Mehrazin R. et al. (2010) Feasibility and efficacy of neoadjuvant sunitinib before nephron-sparing surgery. BJU Int., 106: 1270-6. doi: 10.1111/j.1464-410X.2010.09357.

9. Hellenthal N.J., Underwood W. Penetrante R. et al. (2010) Prospective clinical trial of preoperative sunitinib in patients with renal cell carcinoma. J. Urol., 184(3): 859-864. doi: 10.1016/j.juro.2010.05.041

10. Rini B.I., Plimack E.R., Takagi T. et al. (2015) A phase ll study of pazopanib in patients with localized renal cell carcinoma to optimize preservation of renal parenchyma. J. Urol., 194: 297-303. doi: 10.1016/j.juro.2015.03.096.

11. Lane B.R., Derweesh I.H., Kim H.L. et al. (2015) Presurgical sunitinib reduces tumor size and may facilitate partial nephrectomy in patients with renal cell carcinoma. Urol. Oncol., 33: 112e15-e21. doi: 10.1016/j.urolonc.2014.11.009.

12. Thomas A.A., Rini B.I., Lane B.R. et al. (2009) Response of the primary tumor to neoadjuvant sunitinib in patients with advanced renal cell carcinoma. J. Urol., 181: 518-23. doi: 10.1016/j.juro.2008.10.001.

13. Eisenhauer E.A., Therasse P., Bogaerts J. et al. (2009) New response evaluation criteria in solid tumours: Revised RECIST guideline (version 1.1). Eur. J. Cancer, 45(2): 228-247. doi: 10.1016/j.ejca.2008.10.026.

14. Стаховський Е.О., Войленко О.А., Вітрук Ю.В., Стаховський О.Е. (2015) Застосування нефрометрії для вибору тактики лікування хворих з приводу нирковоклітинного раку. Клінічна хірургія, 3: 55-60.

15. Voylenko O., Vitruk I., Stakhovskyi O. (2014) N.C.I.U. nephrometry and remaining functional parenchyma as a new tool indicator for partial nephrectomy in RCC. Eur. Urol., 13(Suppl. 13): e322.

16. Bindayi A., Hamilton Z.A., McDonald M.L. et al. (2018) Neoadjuvant therapy for localized and locally advanced renal cell carcinoma. Urol. Oncol., 36(1): 31-37. doi: 10.1016/j.urolonc.2017.07.015.

Изменения размера локализованного

почечно-клеточного рака под влиянием

неоадъювантной таргетной терапии

\section{O.A. Войленко}

Национальный институт рака, Киев

Резюме. Цель - определить эффективность использования неоадъювантной таргетной терапии (ТT) в лечении больных локализованным почечно-клеточным раком. Объект $\boldsymbol{u}$ методы. 58 пациентов с локализованным почечно-клеточным раком, которым в период с 2017 по 2018 г. проведено 2 блока неоадъювантной ТТ с определением объективного ответа на лечение и последующим оперативным вмешательством. Pезультаты. Средняя регрессия опухоли после проведения ТТ - 20,5 14,3 (95\% доверительный интервал (ДИ) 16,8$24,3)$. Оценка по RECIST 1.1: стабилизация - 44 (76,9\%) случая; частичная регрессия $-14(24,1 \%)$; полная регрессия -0 ; прогрессия заболевания -0 . Проведение неоадъювантной ТТ способствовало уменьшению размера почечно-клеточного рака в среднем на 12,3 мм с 60,8 $\pm 19,7$ мм (95\% ДИ 55,7-66) до 48,5 $\pm 16,4$ мм (95\% ДИ 44,2-52,8) (t-test; $\mathrm{p}<0,001)$ и увеличению медианы объема функционирующей паренхимы почки на 21\% с 62 (57-77) до 83 (70-90) мм (Mann - Whitney U Test; $\mathrm{p}<0,001)$, что позволило в 53 случаях $(91,4 \%)$ провести резекцию почки. Выводы. Неоадъювантная ТТ у больных с локализованным почечно-клеточным раком обусловила регрессию опухоли в среднем на 20,5 $\pm 14,3 \%$, увеличение медианы объема функционирующей паренхимы почки на $21 \%(\mathrm{p}<0,001)$, что дает возможность проведения дальнейшего органосохраняющего оперативного лечения.

Ключевые слова: почечно-клеточный рак; неоадъювантная таргетная терапия. 


\section{Оригінальні статті / Original Articles}

Changes of the size of localized renal cell carcinoma under the influence of neoadjuvant targeted therapy

o.A. Voylenko

National Cancer Institute, Kyiv

Summary. Objective. To determine efficacy of neoadjuvant targeted therapy (TT) in treatment of patients with localized RCC. Materials and methods. Objective response level and subsequent surgical treatment data of 58 patients with localized renal cell carcinoma (RCC), who underwent 2 cycles of neoadjuvant TT in the period from 2017 to 2018 with. Results. Average regression after TT $-20.5 \pm 14.3$ (95\% confidence interval (CI) 16.8-4.3\%). RECIST 1.1 score: stabile disease -44 (76.9\%) cases; partial regression -14 (24.1\%); complete response -0 ; progressive disease -0 . Conduction of a neoadjuvant TT led to a decrease in the size of the RCC in average up to $12.3 \mathrm{~mm} 60.8 \pm 19.7$ (95\% CI 55.7-66) to $48.5 \pm 16.4 \mathrm{~mm}(95 \% \mathrm{CI} 44.2-52.8)(\mathrm{t}-\mathrm{test} ; \mathrm{p}<0.001)$ and increased median remaining functioning parenchyma volume by $21 \%$ from 62 (57-77) to 83 (70-90) $\mathrm{mm}$ (Mann - Whitney U Test; $\mathrm{p}<0.001)$, which allowed to perform partial nephrectomy in 53 cases (91.4\%). Conclusion. Conducting neoadjuvant TT in patients with localized $\mathrm{RCC}$ resulted in an average regression of tumor by $20.5 \pm 14.3 \%$, increase of median remaining functioning parenchyma volume by $21 \%$ $(p<0.001)$ and high levels of organ-sparing surgery in the group.

Key words: renal cell carcinoma; neoadjuvant targeted therapy.

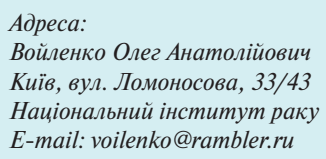

Національний інститут раку

E-mail: voilenko@rambler.ru

Correspondence: Voylenko Oleg 33/43 Lomonosova Str., 03022, Kyiv National Cancer Institute E-mail:voilenko@rambler.ru 